\title{
Research on Mechanical Properties of Angle Beam-column Joint with Gusset plate
}

\author{
Yunan $\mathrm{Li}^{1}$, Xian Dong ${ }^{2 *}$, Zhan Wang ${ }^{3}$, Jiajun $\mathrm{Li}^{1}, \mathrm{Ke} \mathrm{Qin}^{3}$ \\ ${ }^{1}$ Hydraulic and Civil Engineering Department, Inner Mongolia Technical College of Mechanics and Electrics, Huhehot, Inner Mongolia, \\ 010070, China \\ ${ }^{2}$ School of Civil Engineering, Shi Jiazhuang Tiedao University, Shi Jiazhuang, Hebei, 050043, China \\ ${ }^{3}$ Department of Civil Engineering, South China University of Technology, Guangzhou Guangdong, 510640, China
}

\begin{abstract}
There is wide use of beam-column joint with gusset plate angle connection in engineering, however, the mechanical properties of these joints are still lack of complete theoretical and experimental research. This kind of joint is often simplified as an articulated connection or other types of connections in the design. In this paper, experimental study and finite element analysis are carried out to study the flexural behavior of the beam-column joint with gusset plate angle connection. The finite element analysis is used to analyze the differences between the beam-column joint with gusset plate and other joints. The moments-rotation curves and failure modes of the three kinds of beam-column joints were obtained by the static test which were carried out. A more reasonable design of beam-column joint with angle plate of gusset plate is put forward through the research of this paper: the deformation of the column flange is restricted after adding the stiffener, which can avoid the premature yield of the column flange and making the joint have good energy dissipation capacity.
\end{abstract}

\section{Introduction}

Angle beam-column joint with gusset plate connects beam and column by high strength bolt, angle steel and gusset plate welded on the flange of the beam, which can actualize full field assembly. This kind of joint not only has good performance of stiffness, strength and ductility but also has advantages of labor saving, safety, environmental protection, being convenient for industrial production and so on, which is a commonly used connecting method in engineering. In the research of semi-rigid steel frame, gusset plate is often neglected. To simplify the computing process, angle beam-column joint with gusset plate was usually supposed without stiffness when the brace of concentrically braced frame has been failed, which is a hinge joint.

In the 90 s of the last century, lots of research on steel frame joint were carried out. The proposal that the influence of gusset plate on the performance of the joint could not be neglected was raised by experiments ${ }^{1-4}$. After bearing lateral force, considering the composite effect of upper floor, the joint's strength could achieve $30 \sim 40 \%$ plastic bending moment of the beam, and the articulated composite joint has good ductility and strong semi-rigid performance 5 . Domestic researchers used finite element analysis software to analyze the influences of the gusset plate on the rotation stiffness of articulated beam-column joint and on the articulated concentrically braced frame ${ }^{6}$. When the frame structure had interstory deformation, the braced gusset plate would restrain the rotation of the articulated beam-column joint and create additional bending moment in the beam and column, which had 2 kinds of buckling modes: global buckling and free edge buckling by elastic-plastic finite element analysis. The results of the study showed that hinge joint would become semi-rigid joint when the influence of the gusset plate was taken into consideration, which had a great influence on the distribution of internal force of connecting members.

As study of angle beam-column joint with gusset plate is not perfect yet, mechanical behavior of this kind of joint lacks clearly estimating in practical engineering design. In this paper, firstly by using finite element analysis, differences in initial rotational stiffness, ultimate moment bearing capacity and so on of web angle connection joint with gusset plate and common web angle joint are researched, and furthermore that angle connection joint with gusset plate can't be simplified as articulated connection or angle connection with stiffener is revealed. Initial rotational stiffness, failure mode and hysteretic behavior of web angle connection joint with gusset plate are systematic researched by static test .

*Corresponding author's e-mail: wendongxian@163.com 


\section{Comparison of mechanical properties of angle steel connections}

As a panel zone which connect three kind of components who are beam, column and brace, angle beam-column joint with gusset plate is quite different from beam-column joint with double web angle collection or other joints in construction form which will make joint's mechanical behavior different. In this section, 7 different formed finite element models of the joint are set up by ABAQUS, the numerical results of which are processed and analyzed. The model has parameters: the column is $2000 \mathrm{~mm}$ high; the beam is $1000 \mathrm{~mm}$ long; cross section of the column is HM $244 \times 175 \times 7 \times 11$; cross section of the beam is HM194 $\times 150 \times 6 \times 9$; the steel of the beam, column, angle and gusset plate are all Q235; the bolts are 10.9 stage M16 friction type high-strength bolt; the loading mode is displacement loading on the end of the beam. The model construction of different joints are as shown in Figure-1, and the connection types of the model are shown in Table-1. Moment-rotation curves of different types of joints are shown in Figure-2.

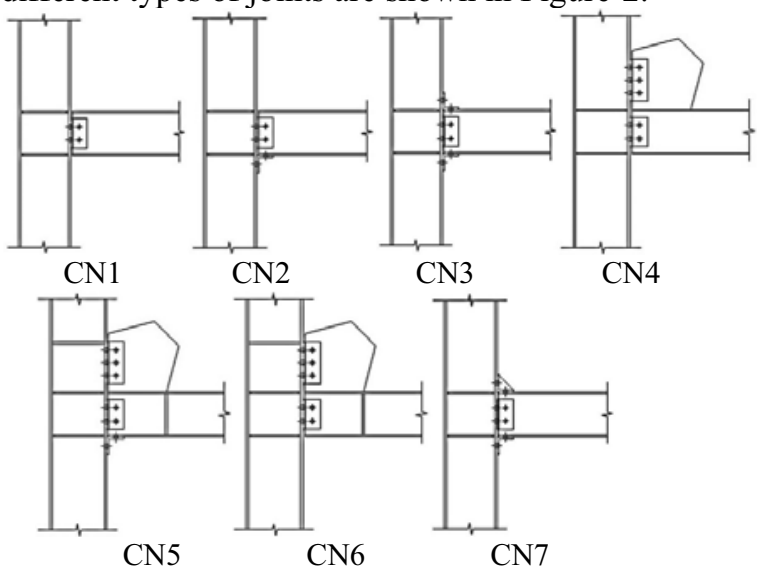

Fig.1 Schematic diagram of different joints

Table 1 Information table of different joints

\begin{tabular}{|c|c|c|}
\hline $\begin{array}{l}\text { Model } \\
\text { number }\end{array}$ & $\begin{array}{l}\text { Connection type of the } \\
\text { joint }\end{array}$ & $\begin{array}{l}\text { Change based } \\
\text { on CN1 }\end{array}$ \\
\hline $\mathrm{CN} 1$ & Double web angle & -- \\
\hline $\mathrm{CN} 2$ & $\begin{array}{l}\text { Double web angle }+ \text { seat } \\
\text { angle }\end{array}$ & + seat angle \\
\hline $\mathrm{CN} 3$ & $\begin{array}{l}\text { Double web } \\
\text { angle+top-and-seat angle }\end{array}$ & $\begin{array}{l}+ \text { top-and-seat } \\
\text { angle }\end{array}$ \\
\hline $\mathrm{CN} 4$ & $\begin{array}{l}\text { Beam-column joint with } \\
\text { gusset plate angle }\end{array}$ & + gusset plate \\
\hline CN5 & $\begin{array}{l}\text { Beam-column joint with } \\
\text { gusset plate angle }\end{array}$ & $\begin{array}{l}+ \text { gusset plate } \\
\text { and stifferner }\end{array}$ \\
\hline CN6 & $\begin{array}{l}\text { Beam-column joint with } \\
\text { gusset plate angle } \\
\text { connection (seat angle) }\end{array}$ & $\begin{array}{l}\text { +gusset plate, } \\
\text { seat angle and } \\
\text { stifferner }\end{array}$ \\
\hline $\mathrm{CN} 7$ & $\begin{array}{l}\text { Double web angle } \\
\text { connection with } \\
\text { top-and-seat angle and } \\
\text { top angle has stiffener }\end{array}$ & $\begin{array}{l}+ \text { top angle with } \\
\text { stifferener and } \\
\text { seat angle }\end{array}$ \\
\hline
\end{tabular}

Table 2 Different types of joints performance comparison

\begin{tabular}{ccccccc}
\hline $\begin{array}{c}\text { Specime } \\
\text { n number }\end{array}$ & $M_{\mathrm{u}}$ & $M_{\mathrm{e}}$ & $M_{P}$ & $K$ & $\begin{array}{c}M_{u l} \\
M_{p l}\end{array}$ & $\begin{array}{c}K / K \\
L\end{array}$ \\
\hline $\mathrm{CN} 1$ & 5.8 & 3.5 & 4.5 & 781 & 0.09 & 0.40 \\
$\mathrm{CN} 2$ & 18 & 7.6 & 13 & 2000 & 0.27 & 1.04 \\
$\mathrm{CN} 3$ & 40 & 15 & 31 & 4120 & 0.59 & 2.13 \\
$\mathrm{CN} 4$ & 93.5 & 23 & 53 & 5702 & 1.39 & 2.95 \\
$\mathrm{CN} 5$ & 97 & 26 & 55 & 6796 & 1.52 & 3.52 \\
$\mathrm{CN} 6$ & 106 & 36 & 88 & 9260 & 1.58 & 4.80 \\
$\mathrm{CN} 7$ & 43 & 16 & 33 & 4600 & 0.64 & 2.38 \\
\hline
\end{tabular}

Comparisons of different types of joints are shown in Table-2. Per Code for design of steel structures, depth-span ratio of Q235 steel beam is 1/15. In this paper, the depth of the beam is $194 \mathrm{~mm}$, corresponding span of which is $2.91 \mathrm{~m}$. The linear stiffness coefficient $K_{l}$ of the beam is $1930 \mathrm{kN} . \mathrm{m}$ and $M_{p l}$ is $63.7 \mathrm{kN} . \mathrm{m}$.

From Table 2, the initial rotational stiffness of CN1 is 0.4 times of the beam's linear stiffness, which belongs to typical articulated joint per Europe code. The initial rotational stiffness of CN4 is 3 times of the beam's linear stiffness. The initial rotational stiffness and ultimate bearing capacity of $\mathrm{CN} 5$ is 9 times and 16 times of CN1's respectively, which indicates that considering the effect of gusset plate or not has great influence on mechanical behavior of the joint, so it can't be simplified as articulated connection. Some scholars simplified beam-column joint with gusset plate as stiffened joint. But from the comparison of $\mathrm{CN} 6$ and $\mathrm{CN} 7$, initial rotational stiffness and ultimate bearing capacity of CN6 is 2 times of CN7's respectively, and the mechanical behaviors of the two kinds of joints are quite different, loading mode of mechanical components of which are different. From the comparison of $\mathrm{CN} 1$ and $\mathrm{CN} 2, \mathrm{CN} 5$ and CN6, seat angle enhances initial stiffness and strength of the joint quite obviously as moment-rotation curves are plumper.

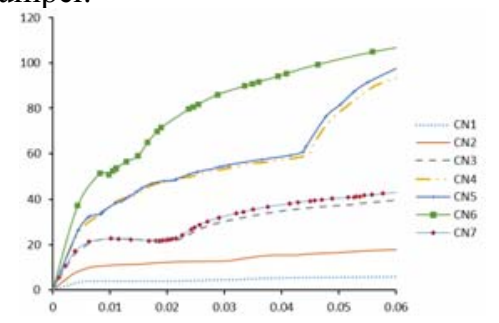

Fig.2 Curves of moment-rotation of different joints

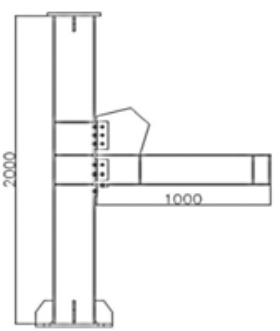

Fig. 3 Specimen model (mm) 


\section{Test research of the joint}

In this section, beam-column joint with gusset plate angle connection is researched by test. Different behaviors of the joint with other angle connection joint are analyzed to provide necessary reference for structural design of the joint. Under horizontal earthquake, after the brace failed, axial force of the column mainly remain unchanged, while joint moment changes alternately, and inflection points of beam and column are closed to the mid-span, so it can be simplified as that column is under static axis load and joint is under static land to research. A typical element whose inflection points of beam and column are both in the mid-span are chosen for the common multiply story center braced steel frame structure under lateral load. Considering that the span of the beam is often 10-20 times of the depth of the beam, choose the length of the cantilever part as $1 \mathrm{~m}$ and the height of the column as $2 \mathrm{~m}$. The specimen model is shown in Figure-3.

The test is named as SJA which is static load test. Specimens of each group are divided into 3 types: basic specimen, add stiffeners to both sides of the column web in the location corresponding to the top of the bolts and add seat angle. Specimen information is shown in Tabel-3, and the detail of the joints is shown in Figure-4. Hot-rolled $\mathrm{H}$ shaped steel is used for specimen beam and column, and the cross sections of them are the same. The cross section of the column is HM244 $\times 175 \times 7 \times 11$ and the cross section of the beam is HM194 $\times 150 \times 6 \times 9$. Steel of beam, column, angle and gusset plate are all Q235. Bolt is 10.9 stage M16 friction type high-strength bolt and torque method is used to fasten. All butt welds are first grade welds, and welding rods are E43. All welding work are finished in the factory. Components are blasted before assembling and slip coefficient of friction surface is 0.45 . Steel from beam web, beam flange, column web and column flange is chosen for materials tension test, and average performance of material is shown in Table-4.

Table 3 Specimen information $(\mathrm{mm})$

\begin{tabular}{|c|c|c|c|c|c|}
\hline $\begin{array}{l}\text { Num } \\
\text { ber }\end{array}$ & Seat angle & $m$ & $\begin{array}{l}\text { Vertical } \\
\text { stiffener of } \\
\text { the column }\end{array}$ & $D$ & Test type \\
\hline $\begin{array}{c}\text { SJA- } \\
1\end{array}$ & none & 2 & none & 16 & $\begin{array}{c}\text { static } \\
\text { monotonic }\end{array}$ \\
\hline $\begin{array}{c}\text { SJA- } \\
2\end{array}$ & none & 3 & $176 \times 72 \times 10$ & 16 & static \\
\hline $\begin{array}{c}\text { SJA- } \\
3\end{array}$ & $\begin{array}{c}\mathrm{L} 75 \times 75 \times \\
10 \times 150\end{array}$ & 3 & $176 \times 72 \times 10$ & 16 & $\begin{array}{l}\text { static } \\
\text { monotonic }\end{array}$ \\
\hline \multicolumn{6}{|c|}{$\begin{array}{l}\text { Note: } m \text { is number of column horizontal stiffeners; } \mathrm{D} \text { is diameter of } \\
\text { Table } 4 \text { Performance of steel material }\end{array}$} \\
\hline & $f_{y}$ & $f_{u}$ & \multicolumn{2}{|c|}{$\mathrm{E}\left(10^{5} \mathrm{~N} / \mathrm{mm}^{2}\right)$} & $\begin{array}{l}\text { Elongation } \\
\text { ratio }\end{array}$ \\
\hline $\begin{array}{l}\text { Aver } \\
\text { of ste }\end{array}$ & 278 & 448 & \multicolumn{2}{|l|}{1.97} & $23.60 \%$ \\
\hline
\end{tabular}

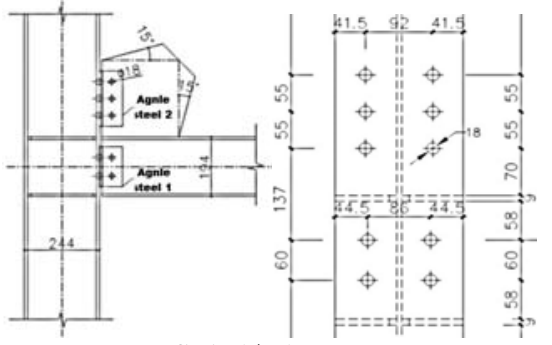

SJA-1/B1

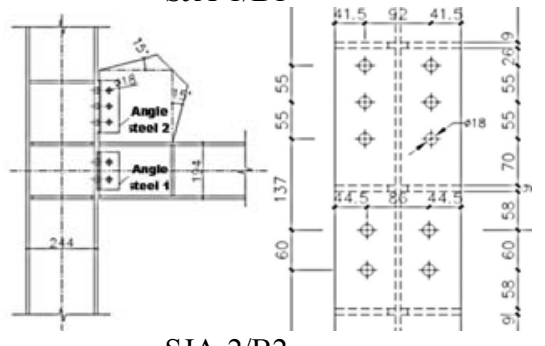

SJA-2/B2

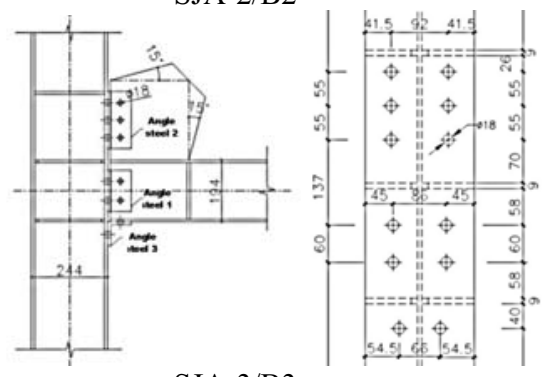

SJA-3/B3

Fig. 4 The detail of the joints $(\mathrm{mm})$

Static test results are shown in Table 5 and moment-rotation curves are shown in Figure 5.

Table 5 Static test results

\begin{tabular}{cccccc}
\hline $\begin{array}{c}\text { Numb } \\
\text { er }\end{array}$ & $M_{\mathrm{u}}$ & $M_{\mathrm{P}}$ & $\boldsymbol{\theta}$ & $K$ & Failure mode \\
\hline SJA-1 & 69 & 49 & 0.076 & 4016 & $\begin{array}{c}\text { displacement was } \\
\text { too large, top flange } \\
\text { of the column was } \\
\text { buckled, and top } \\
\text { angle cracked }\end{array}$ \\
SJA-2 & 81 & 50 & 0.073 & 6018 & $\begin{array}{c}\text { top angle fractured } \\
\text { top angle fractured } \\
\text { and seat angle was } \\
\text { buckled }\end{array}$ \\
\hline
\end{tabular}

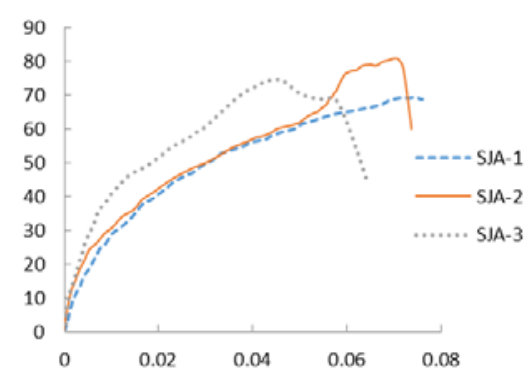

Fig.5 Moment-rotation Curve of SJA

For SJA-1, as stiffener was not set at the top of the column web, tension components were weak and displacement of top angle was large after yielding, so 
local buckling in the compressive panel zone of column web occurred soon. For SJA-2, as stiffener was set at the tension zone of the column web, initial rotational stiffness increased obviously compared with SJA1. As stiffener restrained the deformation of column flange, column flange yielded too early could be avoided, then the behavior of the joint improved. For SJA-3, as seat angle was added, only the lower right part of the column web was buckled when it finally failed. Main stress area and failure mode of the joint changed, and seat angle became main stress component. After the specimens got into nonelastic stage, bearing capacity of the joint increased obviously compared with SJA-2, and performance curves were more plumped. When the rotation angle of the joint is $0.03 \mathrm{rad}$, moment bearing capacity increased by $30 \%$, and ultimate rotation angle decreased. But it still had ductility range, which is bigger than the max rotation angle of the joint according to the code.

\section{Conclusions}

Three kinds of structural formed joints all had large initial rotational stiffness and strength. After they got into plastic stage, bearing capacity increased stably and strengthen stage was long. Ultimate load exceeded 50\% of yielding load, which indicated that beam-column joint with gusset plate angle connection had good ductility which benefitted for seismic.

The beam-column joint with gusset plate angle connection has high initial rotational stiffness, strength and strong ductility, which are favorable for seismic design. The mechanical properties are quite different compared with stiffened angle connection joints. It is not suitable to simplify the joint as articulate joint or simplify the gusset plate as stiffener for design.

\section{Acknowledgments}

This study was supported by the National Natural Science Foundation of China (51808357; 51638009) This study was supported by Natural Science Foundation of Inner Mongolia Autonomous Region(2017MS0517)

\section{Reference}

1. R.M. Richard. Analysis of large bracing connection designs for heavy construction[C].// National Steel Construction Conference Proceedings, American Institute of Steel Construction Chicago, Illinois, 1986, 1-31.

2. Thornton W A. Bracing Connections for Heavy Construction[J]. Tropical Animal Health \& Production, 1984, 19(3):177-178.

3. Uriz P. Towards earthquake resistant design of concentrically braced steel structures[D]. University of California, Berkeley, 2005.

4. Kishiki S, Yamada S, Wade A. Experimental evaluation of structural behavior of gusset plate connections in BRB frame system [C]. // Proceedings, 14th World Conference on Earthquake Engineering. Japan, Tokyo,2008: 12-17.

5. Liu J, Astaneh-Asl A. Cyclic testing of simple connections including effects of slab $[\mathrm{J}]$. Journal of Structural Engineering, 2000, 126(1): 32-39.

6. Mou Wei, analysis of the influence of the gusset plate to the mechanical properties of the speclal braced frame structure eith pinned connections[D]. Harbin, Harbin Institute Of Technology, 2009.

7. Zhang Wenyuan, Zhou Yu, ZhangYaochun. Influence of gusset plate connections on the secondary moments in beams and columns of braced frames[J], Journal of Harbin institute of technology, 2013, 45(006): 1-7.

8. W.A.Thornton. Bracing connections for heavy construction[J]. Engineering Journal AISC, 1984, (3): 139-148.

9. C.M.Hewitt, W.A.Thornton. Rationale behind and proper application of the ductility factor for bracing connections subjected to shear and transverse loading[J]. Engineering Journal,2004, 41(1): 3-6.

10. Ward R C. Improved Seismic Performance of Gusset Plate Connections[J]. Journal of Structural Engineering, 2008, 134(6):890-901.

11. Kim W B, Park H H. Study on the Ultimate Strength of Gusset Plate-Circular Hollow Section(CHS) Joint Stiffened with Rib-plate by End Restraint[J]. Journal of Korean Society of Steel Construction, 2012, 24(4):523-533. 